\title{
The Great Trade Collapse and Rebound: A State-by-State View
}

\author{
Cletus C. Coughlin
}

\begin{abstract}
During the Great Trade Collapse in the United States, which began in late 2008, one concern was that such a large collapse would transform exporting firms into strictly domestic firms or, worse, drive them out of business. In either case, it was feared that U.S. exporting might, at best, revive slowly. However, this fear about long-lived export impacts did not materialize. Clearly there were large export effects, but the sharp decline was quickly followed by a sharp rebound that began in mid-2009. In contrast to previous research, this study examines this historic episode from the perspective of individual states. A comparison of intensive and extensive trade margins reveals that the adjustment occurred to a greater extent on the intensive than on the extensive trade margin. In other words, the adjustment process entailed relatively larger changes in average exports per firm than in the number of exporting firms. It is likely much easier to alter existing export levels than to, first, eliminate all exports by a firm and, second, either restart exports by this firm or become a new entrant into exporting. The bottom line is that the U.S. export sector weathered the challenges associated with the global recession and financial crisis quite well. The fact that relatively large firms dominate U.S. exports likely contributes to the resiliency of the U.S. export sector. (JEL F10, F14, N72, R12)
\end{abstract}

Federal Reserve Bank of St. Louis Review, First Quarter 2014, 96(1), pp. 13-33.

n 2008, U.S. exports of goods totaled \$1,147.4 billion in chained 2005 dollars (Figure 1). As part of the sudden, steep, and synchronized decline in trade worldwide, termed the

"Great Trade Collapse" (GTC) by Baldwin (2009), U.S. exports declined 13.4 percent to $\$ 993.9$ billion in 2009. At the same time, U.S. gross domestic product (GDP) declined 2.8 percent. This collapse was short-lived, as export growth rebounded sharply and exports in 2010 totaled $\$ 1,142.2$ billion, which is roughly the 2008 level. ${ }^{1}$ This 14.9 percent growth in exports substantially exceeded the 2.5 percent increase in GDP during 2010.

This episode in trade history, unprecedented in U.S. post-World War II economic history, affected countries throughout the world and has attracted the attention of many researchers. ${ }^{2}$ Most analyses have relied on country-level data and focused on explanations for the GTC and, to a lesser extent, the subsequent rebound.

Cletus C. Coughlin is senior vice president and chief of staff at the Federal Reserve Bank of St. Louis. The author appreciates the research assistance of Li Li and Diana Cooke.

(c) 2014, The Federal Reserve Bank of St. Louis. The views expressed in this article are those of the author(s) and do not necessarily reflect the views of the Federal Reserve System, the Board of Governors, or the regional Federal Reserve Banks. Articles may be reprinted, reproduced, published, distributed, displayed, and transmitted in their entirety if copyright notice, author name(s), and full citation are included. Abstracts, synopses, and other derivative works may be made only with prior written permission of the Federal Reserve Bank of St. Louis. 


\section{Coughlin}

\section{Figure 1}

\section{U.S. Exports of Goods}

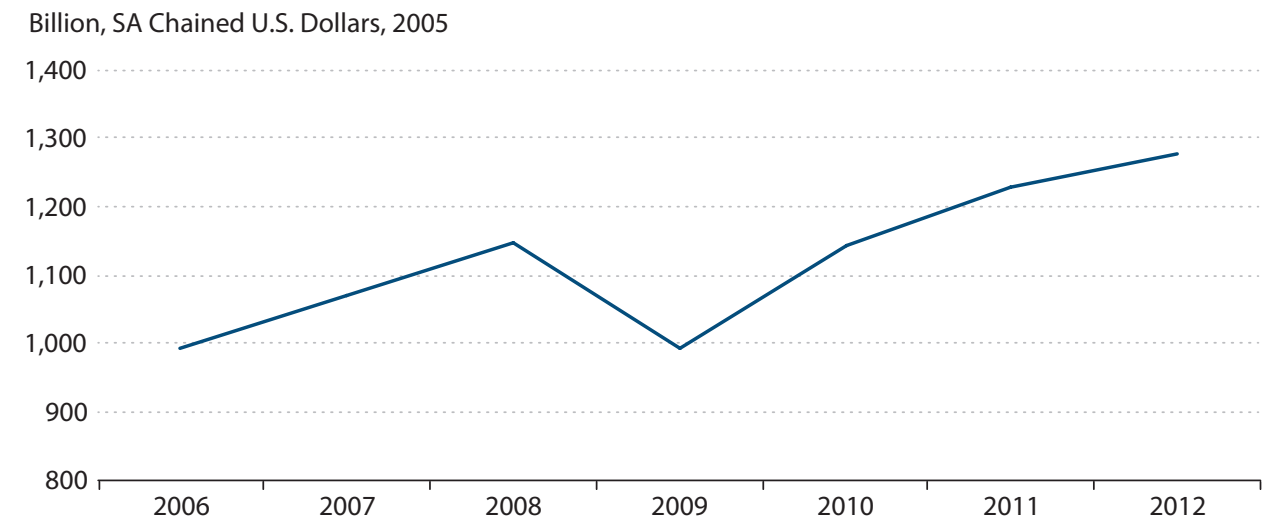

NOTE: The export data are Census-based rather than balance of payments-based. SA, seasonally adjusted.

Crowley and Luo (2011) examine three primary hypotheses for the GTC. ${ }^{3}$ First, and likely the key explanation, is that trade collapsed as a result of a decline in aggregate demand. The fact that trade declined proportionately far more than GDP suggests a demand shock explanation that also accounts for different types of goods, vertical specialization, and inventory adjustments is likely to be important. ${ }^{4,5}$ For example, Eaton et al. (2011) find that more than 80 percent of the decline in the ratio of trade to GDP resulted from a spending shift away from manufactured goods, particularly durable goods.

A second explanation stresses the disruption in the supply of traded goods because of the increased difficulties in securing trade finance during the financial crisis. Generally speaking, most would agree that trade finance conditions deteriorated but that their impact was much less important than the decline in demand. Chor and Manova (2012) find evidence that financing difficulties were a contributing factor, but pinning down their quantitative importance is difficult, partially because of a lack of data. Small- and medium-sized firms were probably affected more by credit constraints than larger firms, which do the bulk of exporting.

A third explanation focuses on increased trade barriers. Despite a frequent finding that import restrictions tend to increase during periods of economic weakness, empirical evidence suggests this explanation is quantitatively unimportant in understanding the GTC. ${ }^{6}$ The rapid rebound in trade also casts doubt on the importance of the import restrictions argument.

My focus is not on the causes of the GTC, but rather on the international trade experiences of U.S. states during the collapse (2008-09) and the rebound (2009-10). Most importantly, the goal is to provide information on the relative importance of the adjustments on the extensive (i.e., the number of exporting firms) and intensive (i.e., the average exports per firm) trade margins. A close look at these margins might provide insights into reasons for the sharp rebound in export growth. Such a sharp rebound was initially viewed as unlikely by many 
because the very large declines in exports during the GTC raised the possibility of long-lived adverse effects on trading relationships. Examining the extensive margin shows how the number of exporting firms changed during the collapse and rebound. Examining the intensive margin shows how the average exports of firms changed. Not surprisingly, I find changes on both margins; however, changes on the intensive margin are found to be relatively more important than changes on the extensive margin during both the collapse and the rebound.

Prior to presenting the analysis, the next section provides a description of the export data used and some basic facts about states and their exporting performance. This description is followed by an analysis of trade margins at the state level. Next, a closer look at state-level exports and their respective trade margins over time and across countries is undertaken. A summary of results and conclusion complete the article.

\section{A NATIONAL OVERVIEW USING STATE EXPORT DATA}

Data on exports by U.S. states to foreign destinations are from the Origin of Movement series. ${ }^{7}$ These data are compiled by the Foreign Trade Division of the U.S. Census Bureau. The data in this series identify the state from which an export begins its journey to a foreign country. Beginning in 1987, the Origin of Movement series provides the current-year export sales, or free-alongside-ship costs if not sold, for all 50 U.S. states to 242 foreign destinations (generally countries). ${ }^{8}$ These export sales are for merchandise sales only and do not include services exports.

Since 1992, the Foreign Trade Division of the U.S. Census Bureau has issued an annual report providing a profile of exporting companies. These reports are based on economic census and survey data on file at the Census Bureau, administrative records from other government agencies, and documents filed for export clearances. Until recently, only exporting companies were profiled, but both exporters and importers are now profiled. ${ }^{9}$ My analysis uses data for 2008, 2009, and 2010 and requires the use of state data-most importantly, state-destination data. The profile contains information on identified companies and their export values. This linkage generates what are termed "known export values." As a result, the data in Table 1 contain entries for total exports, some portion of which cannot be linked to individual exporters, as well as the portion that can be linked. ${ }^{10}$

In 2008, the year prior to the majority of the trade collapse, identified exporters accounted for $\$ 1,150.9$ billion in current-dollar exports, or 89.4 percent of the total value of exported goods. During 2009, known exports declined 18.3 percent. From 2008 to 2009, the number of identified exporters declined from 289,711 to 276,643, a decrease of 4.5 percent. Turning to the rebound, in 2010 identified exporters accounted for $\$ 1,140.4$ billion in exports or 89.2 percent of the total value of exported goods. ${ }^{11}$ Relative to 2009 , known exports rose 21.3 percent in 2010. Meanwhile, the number of identified exporters rose from 276,643 to 293,988, an increase of 6.3 percent.

Using these national data and subsequently adjusting the export values for price changes reveals that adjustments on the intensive margin exceeded adjustments on the extensive margin during both the trade collapse and trade rebound. ${ }^{12}$ For example, during the trade collapse, 


\section{Table 1}

\section{Exports by Identified Companies}

\begin{tabular}{lcrr} 
U.S. Exports and Exporters & $\mathbf{2 0 0 8}$ & $\mathbf{2 0 0 9}$ & $\mathbf{2 0 1 0}$ \\
\hline Total exports (\$ bil.) & $1,287.4$ & $1,056.0$ & $1,278.3$ \\
\hline Known value (Identified exporters) (\$ bil.) & $1,150.9$ & 940.4 & $1,140.4$ \\
Known value/Total exports (\%) & 89.4 & 89.1 & 89.2 \\
No. of identified exporters & 289,711 & 276,643 & 293,988 \\
SOURCE: U.S. Census Bureau. A Profile of U.S. Importing and Exporting Companies, 2010-2011 and prior reports in this \\
series.
\end{tabular}

known exports declined 13.6 percent. A straightforward decomposition of this total change shows that the number of exporting firms declined 4.5 percent and average exports per firm declined 9.6 percent. ${ }^{13}$ Thus, the decline in the intensive margin was more than double that in the extensive margin. ${ }^{14} \mathrm{~A}$ similar, but not as stark, finding pertains to the trade rebound when known exports increased 15.1 percent. Exporting firms increased by 6.3 percent and average exports per firm increased by 8.3 percent. Adjustments clearly occurred on both margins, but these findings suggest that the intensive margin accounts for the majority of the adjustments during both the collapse and the rebound.

This finding is similar to the lack of destruction of trade relationships during the GTC in other countries-France (see Fontagné and Gaulier, 2009), Japan (see Wakasugi, 2009), and Belgium (see Behrens, Corcos, and Mion, 2013). This evidence is also consistent with findings by Schott (2009) for other U.S. "trade shock" episodes. Schott used detailed, firm-level trade data to analyze U.S. firms' responses to the 2001 recession and the 1997 Asian financial crisis and found that the collapse of trade nationally was driven primarily by changes in the intensive margin. In other words, trade fell because firms sold less of what they were already selling rather than eliminating trade altogether. ${ }^{15}$ By using state-level data, I hope to provide additional insights as to the regularity of this finding across states.

I highlight some well-known facts about exporting firms and export markets to provide additional background for the analysis. Despite being outnumbered by smaller firms, relatively large firms dominate U.S. exports. In fact, 287,498 (97.8 percent) of the total 293,988 exporters in 2010 had fewer than 500 employees, while 6,490 exporters (2.2 percent) had 500 or more employees. Nonetheless, large firms ( $>500$ employees) accounted for 66.2 percent of known exports, while relatively small firms ( $<500$ employees) accounted for the remaining 33.8 percent of known exports. In addition, a relatively small number of firms account for the majority of exports. For 2010, the top 50 exporters (roughly 0.02 percent of all exporters) accounted for 29.0 percent of all known exports, and the top 2,000 exporters (roughly 0.68 percent of all exporters) accounted for 76.9 percent of all known exports.

Not surprisingly, relatively large exporters tend to export to more countries than their relatively smaller counterparts. Slightly more than one in four large exporters (26.1 percent) shipped to only one country. These exports accounted for 0.4 percent of the exports of large 
exporters. Meanwhile, smaller exporters were more likely to ship to only one country; as a result, the percentages of these firms and their export shares were larger than those of their larger counterparts. As the number of export destinations increases, the relative importance of large exporters increases. For 2010, 69.3 percent of the exports of large firms were shipped to 50 or more countries. Meanwhile, very few small exporters (roughly 430, or 0.15 percent of all small exporters) shipped to 50 or more countries.

Finally, the top 25 export destinations account for most U.S. exports. For 2010, the top 25 markets accounted for 82.9 percent of U.S. exports. ${ }^{16}$ A similar percentage of U.S. exporters, 81.8 percent, ship to these 25 markets. Not surprisingly, large exporters handle the majority (67.4 percent) of these exports, despite representing a relatively small share (2.6 percent) of the total number of exporters supplying these 25 markets.

Ideally, for the analyses in this article, individual firm data would be used to allow examination of the trading behavior of individual firms. Such data would allow observation of the beginning or ending of a firm's trade involving a specific good or destination and the change in the value of a firm's ongoing trade involving a specific good or destination. In the present case, I have state-level data, so I am limited to using the number of firms in a state that export to a specific country.

The state-level data limitation highlights the distinction between plants and firms. Because a firm with plants in different states could export to a given country from plants in different states, the sum of the number of exporters over all states would exceed the number of exporters nationally. Also, a firm with plants in multiple states might export to different countries depending on the plant. If the exporters over all countries were summed, this sum would exceed the number of exporters at the national level. Thus, the analysis here combines single-plant firms with multiplant firms.

Why might combining single- and multiplant firms matter? The response to a decline (or an increase) in foreign demand can differ between a single-plant firm and a multiplant firm. For example, assume a firm has plants in two states and that both plants produce exports for the same foreign country. In response to a decline in foreign demand, the firm might choose to serve the foreign country from one plant rather than two. As a result, from the firm's perspective, the adjustment is completely on the intensive margin, while from a plant's perspective, the adjustment differs across states. From the perspective of one state, there is a decline on the extensive margin and an uncertain change on the intensive margin, while from the perspective of the other state, there is no change on the extensive margin. Any change is on the intensive margin. The key point of this example is that the dynamics based on firms can differ from the dynamics based on plants. Any interpretation of the results in this article must keep this possibility in mind.

Table 2 contains summary information, by state, for the number of foreign destinations with export activity. ${ }^{17}$ Virtually every state serves the top 30 export markets. Moreover, even during the GTC, more often than not the number of export destinations tended to increase. Relative to 2008, 27 states in 2009 experienced an increase in export destinations, 18 states a decrease, and 5 states no change. Especially noteworthy is that every state in New England added 30 or more export destinations. Only one state, North Dakota, suffered a double-digit 


\section{Coughlin}

Table 2

Number of Export Destinations by State

\begin{tabular}{|c|c|c|c|c|c|}
\hline State & $\begin{array}{c}\text { Total level } \\
2008\end{array}$ & $\begin{array}{l}\text { Change } \\
\text { 2008-09 }\end{array}$ & $\begin{array}{c}\text { Total level } \\
2009\end{array}$ & $\begin{array}{l}\text { Change } \\
2009-10\end{array}$ & $\begin{array}{c}\text { Total level } \\
2010\end{array}$ \\
\hline Alabama & 129 & -9 & 120 & 48 & 168 \\
\hline Alaska & 34 & 2 & 36 & 49 & 85 \\
\hline Arizona & 143 & -7 & 136 & 43 & 179 \\
\hline Arkansas & 101 & -7 & 94 & 53 & 147 \\
\hline California & 184 & 1 & 185 & 8 & 193 \\
\hline Colorado & 128 & -2 & 126 & 49 & 175 \\
\hline Connecticut & 138 & 37 & 175 & -2 & 173 \\
\hline Delaware & 87 & -2 & 85 & 49 & 134 \\
\hline Florida & 178 & -1 & 177 & 15 & 192 \\
\hline Georgia & 165 & 2 & 167 & 22 & 189 \\
\hline Hawaii & 44 & -2 & 42 & 43 & 85 \\
\hline Idaho & 84 & -2 & 82 & 55 & 137 \\
\hline Illinois & 166 & 20 & 186 & 2 & 188 \\
\hline Indiana & 142 & 33 & 175 & -5 & 170 \\
\hline lowa & 120 & 0 & 120 & 45 & 165 \\
\hline Kansas & 125 & -1 & 124 & 49 & 173 \\
\hline Kentucky & 117 & 9 & 126 & 39 & 165 \\
\hline Louisiana & 137 & 1 & 138 & 36 & 174 \\
\hline Maine & 96 & 53 & 149 & 9 & 158 \\
\hline Maryland & 157 & -8 & 149 & 30 & 179 \\
\hline Massachusetts & 156 & 30 & 186 & -2 & 184 \\
\hline Michigan & 139 & 41 & 180 & -5 & 175 \\
\hline Minnesota & 150 & 1 & 151 & 28 & 179 \\
\hline Mississippi & 108 & 0 & 108 & 48 & 156 \\
\hline Missouri & 131 & 1 & 132 & 37 & 169 \\
\hline Montana & 61 & -3 & 58 & 42 & 100 \\
\hline Nebraska & 101 & 6 & 107 & 47 & 154 \\
\hline Nevada & 109 & 2 & 111 & 37 & 148 \\
\hline New Hampshire & 106 & 46 & 152 & -2 & 150 \\
\hline New Jersey & 166 & 24 & 190 & -5 & 185 \\
\hline New Mexico & 79 & 3 & 82 & 57 & 139 \\
\hline New York & 172 & 19 & 191 & -2 & 189 \\
\hline North Carolina & 157 & -1 & 156 & 27 & 183 \\
\hline North Dakota & 79 & -11 & 68 & 48 & 116 \\
\hline Ohio & 162 & 27 & 189 & -4 & 185 \\
\hline Oklahoma & 118 & -4 & 114 & 46 & 160 \\
\hline Oregon & 124 & 1 & 125 & 52 & 177 \\
\hline Pennsylvania & 161 & 27 & 188 & 4 & 192 \\
\hline Rhode Island & 95 & 41 & 136 & -1 & 135 \\
\hline South Carolina & 144 & 1 & 145 & 28 & 173 \\
\hline South Dakota & 64 & 0 & 64 & 44 & 108 \\
\hline Tennessee & 144 & 0 & 144 & 38 & 182 \\
\hline Texas & 176 & -1 & 175 & 15 & 190 \\
\hline Utah & 123 & 5 & 128 & 42 & 170 \\
\hline Vermont & 86 & 43 & 129 & 1 & 130 \\
\hline Virginia & 162 & -3 & 159 & 26 & 185 \\
\hline Washington & 158 & -6 & 152 & 34 & 186 \\
\hline West Virginia & 76 & -2 & 74 & 36 & 110 \\
\hline Wisconsin & 148 & 32 & 180 & -2 & 178 \\
\hline Wyoming & 43 & 0 & 43 & 48 & 91 \\
\hline
\end{tabular}




\section{Figure 2}

Export Destinations and State Size (2010)

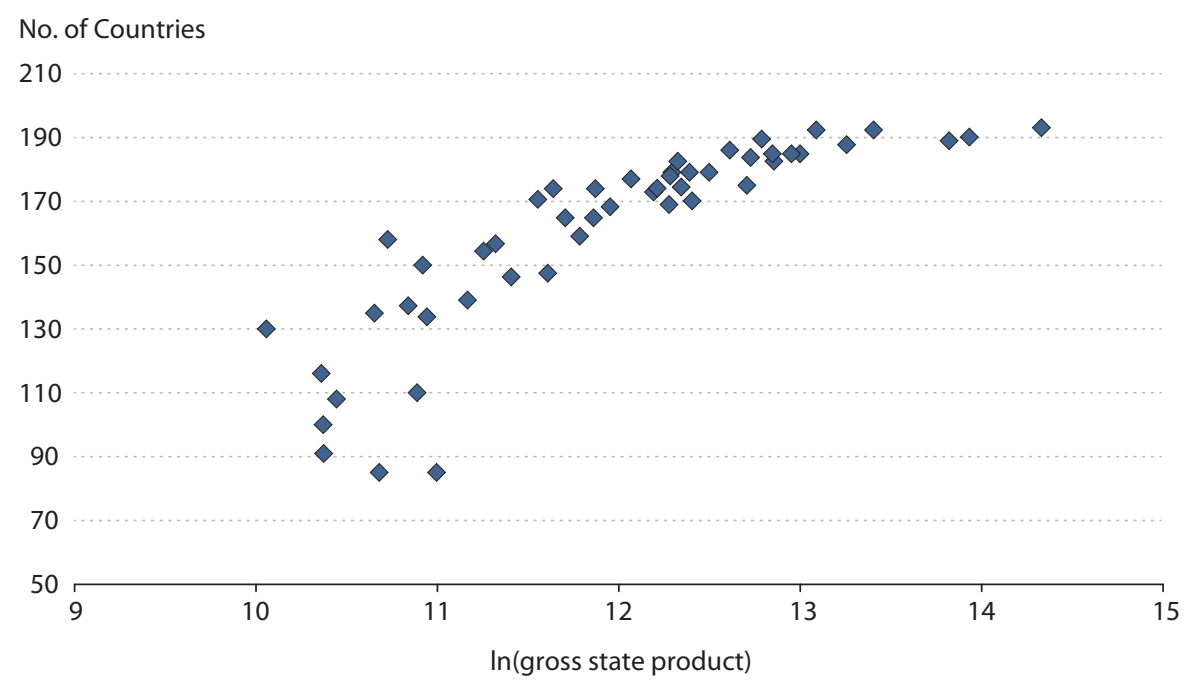

SOURCE: WISER and Bureau of Economic Analysis.

loss (11) in the number of export destinations. Not surprisingly, in light of the rebound, the vast majority of states (40) served more export destinations in 2010 than in 2009 . No state suffered a loss of more than five export destinations.

Figures 2 through 4 show some noteworthy differences across states. Figure 2, which uses 2010 data, shows the positive relationship between state size (gross state product in natural logarithms) and the number of destination countries. ${ }^{18}$ In other words, larger states tend to export to more countries. The three largest U.S. states-California, New York, and Texasexport to many more countries than the five smallest states-South Dakota, Wyoming, Montana, North Dakota, and Vermont. Figure 2 also shows that the rate of increase in the number of destination countries decreases as state size increases. For the largest states, the number of destination countries approaches 200.

Figure 3 shows that larger foreign countries (higher GDPs in natural logarithms) tend to import from a larger number of U.S. states. Moreover, once a country's GDP reaches a certain size, it generally imports from all 50 states. ${ }^{19}$ All countries with GDPs larger than $\$ 401$ billion import from every state, while the 10 countries with the smallest GDPs imported from an average of slightly more than 21 states.

Figure 4 shows the number of exporters in a state is related positively to state size (gross state product in natural logarithms). ${ }^{20}$ For example, the number of exporters in the largest states-California (72,092 exporters), New York $(40,377)$, and Texas $(38,276)$ - exceeds the number in the smallest states-South Dakota (965 exporters), Wyoming (421), Montana $(1,539)$, North Dakota $(1,870)$, and Vermont $(1,244)$ - by a factor of more than 20 . Figure 4 


\section{Coughlin}

\section{Figure 3}

States and Export Destination Size (2010)

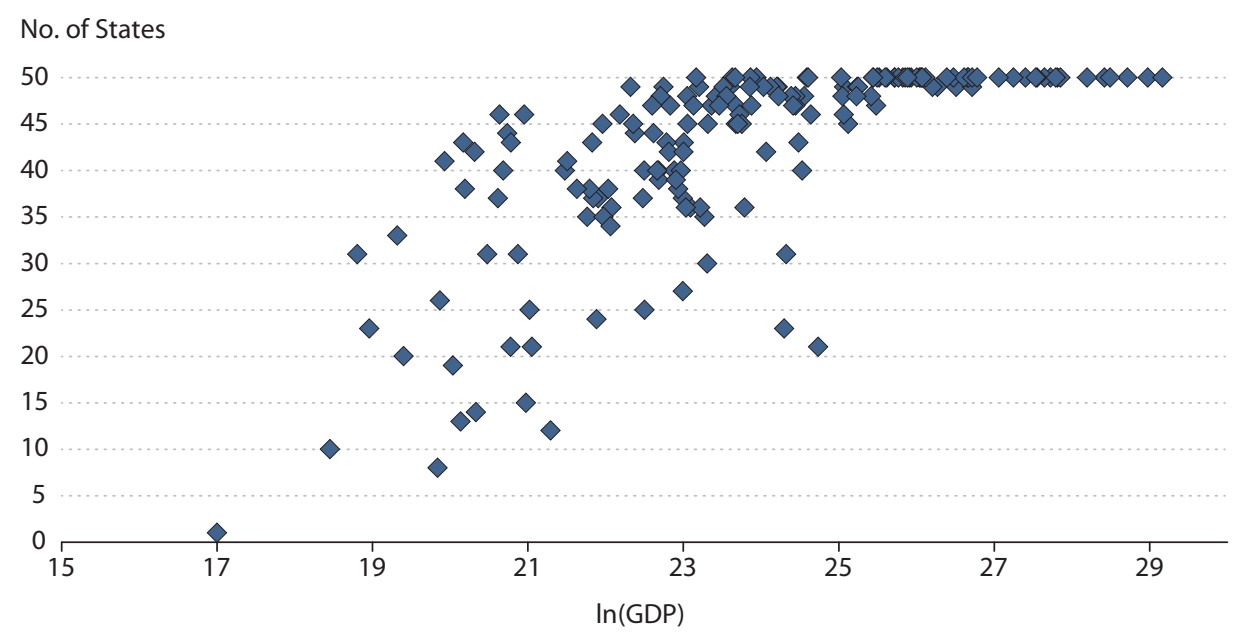

SOURCE: WISER and the World Bank.

Figure 4

\section{Exporters and State Size (2010)}

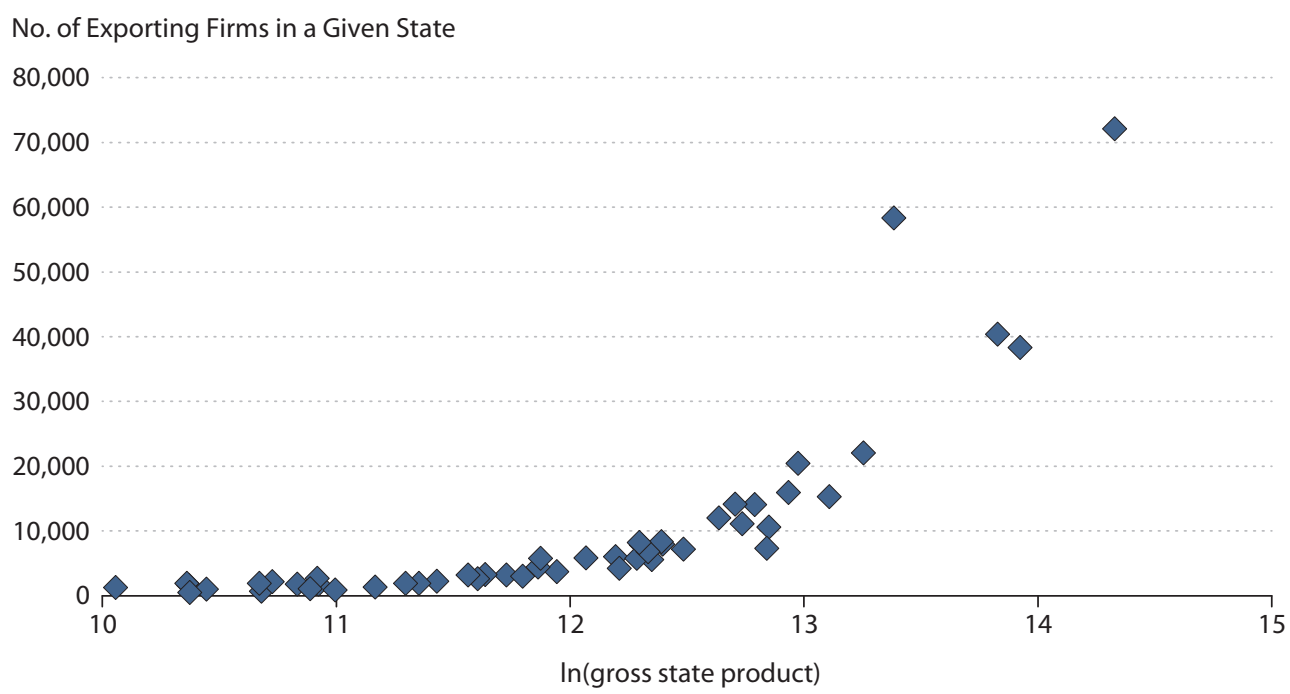

SOURCE: U.S. Census Bureau and the World Bank. 
also reveals that a given change in gross state product is associated with increases in exporters at an increasing rate.

\section{TRADE MARGINS DURING THE GREAT TRADE COLLAPSE AND REBOUND}

As I did for the decomposition of the percentage change in exports at the national level in the previous section, here I undertake the same calculation at the level of individual states. First, I examine changes during the 2008-09 GTC and, second, I examine changes during the 2009-10 trade rebound. ${ }^{21}$

During the GTC, known exports declined 13.6 percent nationally; all states but Alaska and Utah experienced a decline in known exports. ${ }^{22}$ Exports from Alaska increased 3.2 percent and exports from Utah increased 6.5 percent. Meanwhile, exports from New Mexico declined the most: -53.7 percent.

As shown in Table 3, decreasing exports resulted from declines on both the extensive and intensive margins for most states. For example, the number of exporting firms declined in all but four states-Delaware, Louisiana, Maryland, and Rhode Island. The number of exporting firms declined even in the two states in which exports increased. Not surprisingly, large states, such as California and New York, suffered the largest absolute declines in exporters, with each state losing more than 2,000 exporting firms. Small states, such as Montana, South Dakota, and North Dakota, suffered the largest percentage declines in exporters. Each of these states experienced a decline in exporting firms of more than 14 percent.

While the number of exporting firms generally declined across states during the GTC, exports per firm across states also tended to decline. Exports per firm declined in all but nine states-Alaska, Arkansas, Connecticut, Kentucky, Nebraska, Nevada, North Dakota, Utah, and Vermont. Alaska, with a 14.9 percent increase in exports per firm, had the largest percentage increase, while New Mexico, with a 51.6 percent decline, had the largest decrease.

In comparing the percentage changes in the extensive and intensive margins, declines on the intensive margin exceed those on the extensive margin in 33 of the 50 states. Thus, not surprisingly in light of the national numbers, relatively more of the adjustment occurs in terms of exports per firm than in the numbers of exporters. ${ }^{23}$

Table 4 restates the results in Table 3 to highlight the ranking of states based on the relative importance of the percentage change in the intensive margin as a share of the percentage change in exports. During the GTC, seven states show percentage changes in the intensive margin relative to exports that are 1 or larger. The values for Alaska and Utah reflect the importance of the positive changes in the intensive margin in accounting for increased exports. The values for Delaware, Maryland, Rhode Island, Louisiana, and Florida reflect the importance of the negative changes in the intensive margin in accounting for the decrease in exports.

Exports rose in nearly all states during the 2009-10 rebound. Export growth was most pronounced in Maine and New Hampshire, where growth exceeded 36 percent. The exceptions to positive export growth were Arkansas, Nevada, and Washington. Exports from Arkansas declined almost 11 percent. 


\section{Coughlin}

Table 3

Decomposition of Trade Changes

\begin{tabular}{|c|c|c|c|c|c|c|c|c|}
\hline \multirow[b]{2}{*}{ State } & \multicolumn{4}{|c|}{ GTC (2008-09) } & \multicolumn{4}{|c|}{ Rebound (2009-10) } \\
\hline & $\begin{array}{c}\text { Extensive } \\
\text { margin }\end{array}$ & $\begin{array}{l}\text { Intensive } \\
\text { margin }\end{array}$ & $\begin{array}{c}\text { Joint } \\
\text { change }\end{array}$ & $\begin{array}{l}\text { Change in } \\
\text { exports (\%) }\end{array}$ & $\begin{array}{c}\text { Extensive } \\
\text { margin }\end{array}$ & $\begin{array}{c}\text { Intensive } \\
\text { margin }\end{array}$ & $\begin{array}{c}\text { Joint } \\
\text { change }\end{array}$ & $\begin{array}{l}\text { Change in } \\
\text { exports (\%) }\end{array}$ \\
\hline United States & -4.5 & -9.6 & 0.4 & -13.6 & 6.3 & 8.3 & 0.5 & 15.1 \\
\hline Alabama & -5.0 & -14.4 & 0.7 & -18.6 & 1.3 & 23.8 & 0.3 & 25.5 \\
\hline Alaska & -10.2 & 14.9 & -1.5 & 3.2 & 12.4 & 5.8 & 0.7 & 18.9 \\
\hline Arizona & -3.7 & -22.3 & 0.8 & -25.2 & 10.8 & -3.5 & -0.4 & 6.9 \\
\hline Arkansas & -8.0 & 5.8 & -0.5 & -2.6 & 12.1 & -20.4 & -2.5 & -10.8 \\
\hline California & -3.0 & -8.8 & 0.3 & -11.5 & 6.1 & 7.1 & 0.4 & 13.7 \\
\hline Colorado & -5.6 & -15.3 & 0.9 & -20.0 & 9.3 & 0.5 & 0.0 & 9.9 \\
\hline Connecticut & -6.1 & 5.5 & -0.3 & -0.9 & 6.2 & 1.7 & 0.1 & 7.9 \\
\hline Delaware & 10.2 & -14.0 & -1.4 & -5.3 & 12.7 & -6.0 & -0.8 & 6.0 \\
\hline Florida & 0.0 & -8.4 & 0.0 & -8.4 & 5.5 & 6.8 & 0.4 & 12.6 \\
\hline Georgia & -4.0 & -4.9 & 0.2 & -8.7 & 5.3 & 9.5 & 0.5 & 15.3 \\
\hline Hawaii & -4.3 & -10.7 & 0.5 & -14.5 & 9.3 & 1.3 & 0.1 & 10.7 \\
\hline Idaho & -10.8 & -3.4 & 0.4 & -13.8 & 13.7 & 10.8 & 1.5 & 26.0 \\
\hline Illinois & -5.2 & -13.8 & 0.7 & -18.3 & 5.2 & 9.4 & 0.5 & 15.2 \\
\hline Indiana & -5.5 & -2.9 & 0.2 & -8.2 & 5.5 & 12.9 & 0.7 & 19.1 \\
\hline lowa & -8.6 & -13.4 & 1.2 & -20.8 & 10.6 & 3.2 & 0.3 & 14.1 \\
\hline Kansas & -2.3 & -27.6 & 0.6 & -29.2 & 6.9 & -1.6 & -0.1 & 5.2 \\
\hline Kentucky & -5.3 & 3.1 & -0.2 & -2.3 & 6.9 & -1.4 & -0.1 & 5.4 \\
\hline Louisiana & 0.3 & -18.6 & -0.1 & -18.3 & 5.2 & 13.2 & 0.7 & 19.1 \\
\hline Maine & -8.2 & -16.2 & 1.3 & -23.0 & 5.9 & 30.9 & 1.8 & 38.7 \\
\hline Maryland & 2.4 & -16.1 & -0.4 & -14.1 & 14.1 & -7.6 & -1.1 & 5.4 \\
\hline Massachusetts & -4.4 & -7.8 & 0.3 & -11.9 & 6.4 & -0.3 & 0.0 & 6.1 \\
\hline Michigan & -6.7 & -17.2 & 1.2 & -22.8 & 5.4 & 24.1 & 1.3 & 30.8 \\
\hline Minnesota & -5.2 & -9.8 & 0.5 & -14.5 & 7.2 & 7.7 & 0.6 & 15.5 \\
\hline Mississippi & -4.3 & -10.3 & 0.4 & -14.2 & 7.5 & 22.2 & 1.7 & 31.4 \\
\hline Missouri & -6.6 & -16.0 & 1.0 & -21.5 & 6.4 & 22.2 & 1.4 & 30.0 \\
\hline Montana & -17.4 & -1.6 & 0.3 & -18.7 & 16.4 & 7.8 & 1.3 & 25.4 \\
\hline Nebraska & -7.1 & 1.5 & -0.1 & -5.7 & 7.0 & 7.4 & 0.5 & 15.0 \\
\hline Nevada & -5.7 & 5.4 & -0.3 & -0.7 & 8.0 & -10.0 & -0.8 & -2.7 \\
\hline New Hampshire & -7.3 & -5.3 & 0.4 & -12.2 & 10.7 & 23.6 & 2.5 & 36.8 \\
\hline New Jersey & -4.4 & -13.4 & 0.6 & -17.2 & 1.8 & 9.0 & 0.2 & 10.9 \\
\hline New Mexico & -4.3 & -51.6 & 2.2 & -53.7 & 6.6 & 5.1 & 0.3 & 12.1 \\
\hline New York & -5.6 & -14.4 & 0.8 & -19.2 & 5.9 & 7.9 & 0.5 & 14.2 \\
\hline North Carolina & -2.7 & -5.9 & 0.2 & -8.4 & 8.0 & 1.1 & 0.1 & 9.2 \\
\hline North Dakota & -14.6 & 1.7 & -0.3 & -13.1 & 17.2 & -6.5 & -1.1 & 9.7 \\
\hline Ohio & -5.5 & -17.9 & 1.0 & -22.4 & 5.4 & 14.6 & 0.8 & 20.9 \\
\hline Oklahoma & -5.4 & -2.4 & 0.1 & -7.7 & 2.9 & 12.2 & 0.4 & 15.5 \\
\hline Oregon & -7.0 & -11.2 & 0.8 & -17.4 & 7.2 & 3.4 & 0.2 & 10.9 \\
\hline Pennsylvania & -5.5 & -7.7 & 0.4 & -12.8 & 5.8 & 10.9 & 0.6 & 17.4 \\
\hline Rhode Island & 1.6 & -23.0 & -0.4 & -21.8 & 0.2 & 26.9 & 0.0 & 27.1 \\
\hline South Carolina & -6.5 & -4.7 & 0.3 & -10.9 & 5.4 & 10.7 & 0.6 & 16.7 \\
\hline South Dakota & -16.0 & -25.7 & 4.1 & -37.6 & 7.1 & 9.8 & 0.7 & 17.6 \\
\hline Tennessee & -4.5 & -1.3 & 0.1 & -5.7 & 5.0 & 14.9 & 0.7 & 20.7 \\
\hline Texas & -1.4 & -9.2 & 0.1 & -10.5 & 6.5 & 14.5 & 0.9 & 21.9 \\
\hline Utah & -2.2 & 8.9 & -0.2 & 6.5 & 7.8 & 12.1 & 0.9 & 20.8 \\
\hline Vermont & -9.3 & 2.5 & -0.2 & -7.1 & 4.3 & 24.0 & 1.0 & 29.3 \\
\hline Virginia & -7.2 & -7.3 & 0.5 & -13.9 & 3.2 & 4.7 & 0.1 & 8.1 \\
\hline Washington & -4.9 & -14.2 & 0.7 & -18.4 & 6.7 & -7.8 & -0.5 & -1.6 \\
\hline West Virginia & -3.8 & -10.2 & 0.4 & -13.5 & 8.1 & 16.9 & 1.4 & 26.4 \\
\hline Wisconsin & -3.9 & -9.9 & 0.4 & -13.4 & 4.1 & 7.8 & 0.3 & 12.2 \\
\hline Wyoming & -8.3 & -1.8 & 0.2 & -10.0 & 11.7 & -7.0 & -0.8 & 3.8 \\
\hline
\end{tabular}


Table 4

Relative Importance of Intensive Margin Changes

Intensive Margin Relative to Percent Change in Exports

\begin{tabular}{|c|c|c|c|}
\hline State & GTC (2008-09) & Origin & Rebound (2009-10) \\
\hline Alaska & 4.70 & Washington & 4.97 \\
\hline Delaware & 2.66 & Nevada & 3.64 \\
\hline Utah & 1.37 & Arkansas & 1.89 \\
\hline Maryland & 1.14 & Rhode Island & 0.99 \\
\hline Rhode Island & 1.06 & Alabama & 0.93 \\
\hline Louisiana & 1.01 & New Jersey & 0.82 \\
\hline Florida & 1.00 & Vermont & 0.82 \\
\hline New Mexico & 0.96 & Maine & 0.80 \\
\hline Kansas & 0.94 & Oklahoma & 0.79 \\
\hline Arizona & 0.89 & Michigan & 0.78 \\
\hline Texas & 0.88 & Missouri & 0.74 \\
\hline Ohio & 0.80 & Tennessee & 0.72 \\
\hline New Jersey & 0.78 & Mississippi & 0.71 \\
\hline Alabama & 0.77 & Ohio & 0.70 \\
\hline Washington & 0.77 & Louisiana & 0.69 \\
\hline Colorado & 0.76 & Indiana & 0.68 \\
\hline California & 0.76 & Texas & 0.66 \\
\hline Illinois & 0.76 & South Carolina & 0.64 \\
\hline Michigan & 0.76 & New Hampshire & 0.64 \\
\hline West Virginia & 0.75 & Wisconsin & 0.64 \\
\hline New York & 0.75 & West Virginia & 0.64 \\
\hline Missouri & 0.74 & Pennsylvania & 0.63 \\
\hline Wisconsin & 0.74 & Illinois & 0.62 \\
\hline Hawaii & 0.73 & Georgia & 0.62 \\
\hline Mississippi & 0.73 & Virginia & 0.59 \\
\hline United States & 0.71 & Utah & 0.58 \\
\hline Maine & 0.70 & South Dakota & 0.56 \\
\hline North Carolina & 0.70 & New York & 0.55 \\
\hline South Dakota & 0.68 & United States & 0.55 \\
\hline Minnesota & 0.68 & Florida & 0.53 \\
\hline Massachusetts & 0.66 & California & 0.52 \\
\hline lowa & 0.64 & Minnesota & 0.50 \\
\hline Oregon & 0.64 & Nebraska & 0.50 \\
\hline Pennsylvania & 0.60 & New Mexico & 0.42 \\
\hline Georgia & 0.57 & Idaho & 0.41 \\
\hline Virginia & 0.52 & Oregon & 0.31 \\
\hline New Hampshire & 0.43 & Alaska & 0.31 \\
\hline South Carolina & 0.43 & Montana & 0.30 \\
\hline Indiana & 0.35 & lowa & 0.23 \\
\hline Oklahoma & 0.32 & Connecticut & 0.21 \\
\hline Idaho & 0.25 & Hawaii & 0.12 \\
\hline Tennessee & 0.22 & North Carolina & 0.12 \\
\hline Wyoming & 0.18 & Colorado & 0.05 \\
\hline Montana & 0.09 & Massachusetts & -0.04 \\
\hline North Dakota & -0.13 & Kentucky & -0.26 \\
\hline Nebraska & -0.26 & Kansas & -0.31 \\
\hline Vermont & -0.34 & Arizona & -0.51 \\
\hline Kentucky & -1.35 & North Dakota & -0.67 \\
\hline Arkansas & -2.20 & Delaware & -1.00 \\
\hline Connecticut & -5.89 & Maryland & -1.42 \\
\hline Nevada & -8.08 & Wyoming & -1.83 \\
\hline
\end{tabular}




\section{Coughlin}

As shown in Table 3, rising exports resulted from increases on the extensive margin for all states and increases on the intensive margin for most states. The growth in the number of exporting firms exceeded 10 percent in 11 states-Alaska, Arizona, Arkansas, Delaware, Idaho, Iowa, Maryland, Montana, New Hampshire, North Dakota, and Wyoming.

Results for the intensive margin reveal that 39 of the 50 states experienced increases; in 8 states the increases exceeded 22 percent. Maine led the way with an increase of more than 30 percent, which accounts for its overall large percentage increase in exports. For the 11 states with declines in their intensive margins, the 20.4 percent decline in Arkansas was more than double the decline in Nevada, which experienced the second-largest decline. Obviously, the decline in Arkansas is the key factor accounting for the overall decline in its exports.

When the percentage changes in the extensive and intensive margins are compared, increases on the intensive margin exceeded those on the extensive margin in 29 states during the rebound. Thus (not surprisingly) in light of the national numbers and similar to the finding during the GTC, relatively more of the adjustment occurred in terms of exports per firm than in the numbers of exporters. ${ }^{24}$

Table 4 ranks states based on the relative importance of the percentage change in the intensive margin as a share of the percentage change in exports. Washington, Nevada, and Arkansas, the exceptions to positive growth in known exports during the rebound, lead the way. Rhode Island and Alabama are the fourth- and fifth-ranked states. In both cases, positive changes in the intensive margin account for more than 90 percent of the change in exports.

\section{TRADE DURING THE COLLAPSE AND REBOUND: TIME, SIZE, GEOGRAPHIC, AND DEMAND PERSPECTIVES}

So far, I have explored the trade collapse and rebound separately without regard to possible connections over time or over space. This section presents an elementary-level exploration of some of the many possible relationships, beginning with a focus on time and then considering other perspectives.

\section{Time Perspective}

Are there any obvious connections between the two periods with respect to time? For example, do states with relatively larger trade collapses have relatively larger trade rebounds? At most, I find an association for such a relationship that is very weak and not statistically significant. The correlation between the percentage changes in known exports across states for the two periods is -0.16 , which is not statistically significant at the 5 percent level. For total exports, the correlation coefficient is -0.20 , which is also not statistically significant at the 5 percent level. Similarly, I find no statistically significant association for the percentage change in the intensive margin across states for the two periods. The correlation coefficient is -0.16 . However, with a correlation coefficient of -0.28 , I do find a statistically significant association for the percentage change in the extensive margin across states for the two periods. In other words, states with relatively larger declines in their extensive margins experienced relatively larger rebounds in this margin. 


\section{Size Perspective}

This section explores whether there are differences during either period based on state size. State size does not appear to be associated with the change in exports. For example, the correlation between state GDP in 2008 and the percentage change in total exports during the collapse is 0.04 , and the correlation between state GDP in 2009 and the percentage change in total exports during the rebound is -0.14 . Neither is statistically significant at the 5 percent level.

No statistically significant relationship is found between the intensive margin and state size for either the collapse or the rebound. The correlation coefficient is -0.07 for the collapse and 0.02 for the rebound, neither of which is statistically significant at the 5 percent level. Meanwhile, state size is associated with the extensive margin. During the collapse, larger states tended to have relatively smaller declines in their extensive margins; similarly, during the rebound, larger states tended to have relatively smaller increases in their extensive margins. In the former case, the correlation coefficient is 0.24 , while in the latter case, the correlation coefficient is -0.26 . While neither case is statistically significant at the 5 percent level, both are statistically significant at the 10 percent level.

\section{Geographic Perspective}

One way to assess the similarity in the changes in trade margins and exports of nearby states from a geographic perspective is to calculate the Moran's I spatial statistic. This statistic, with a range of +1 to -1 , indicates clustering when its value is close to +1 and dispersion when its value is close to -1 . If states with high values are located near other states with high values and states with low values are located near other states with low values, then the associated Moran's I value will be close to 1 . Meanwhile, if a state with a high value tends to be located near a state with a low value (and vice versa), then the associated Moran's I value will be close to -1 . If there is no pattern (i.e., random), then the value will be near zero. ${ }^{25}$

I use the trade margin measures in Table 3 and the percentage changes in total and known exports during both the collapse and the rebound to calculate the associated Moran's I statistic for a number of cases. For the intensive margin, I find a random geographic distribution across the 48 contiguous U.S. states. ${ }^{26}$ In other words, the Moran's I values are close to zero: -0.10 for 2008-09 and -0.06 for 2009-10, suggesting no statistical association.

The maps in Figures 5 and 6 reflect this lack of geographic association for the intensive margin. Figure 5 shows the quintile distribution by state on the intensive margin for the trade collapse, while Figure 6 pertains to the rebound. The lightest color shows the states in the lowest (smallest values) quintile, while the darkest color shows the states in the highest (largest values) quintile. A positive association would be suggested by a clustering of states with the same color, while a negative association would be suggested by states with the lightest color that are contiguous to states with the darkest color. No association would be suggested by a random distribution of the colors of the states. Both maps reveal a random distribution. For example, in both Figures 5 and 6, states with the lowest values are scattered throughout the country; in no instance are more than two of these states contiguous. 


\section{Coughlin}

For the extensive margin, during both the collapse and the rebound, I find a positive association at the 0.05 percent statistical significance level. For the collapse, the Moran's I value is 0.33 ; for the rebound, the value is 0.18 . The maps in Figures 7 and 8 show this positive association as states of a similar color tend to cluster. For example, in Figure 7, states with the lowest values-Maine, New Hampshire, and Vermont plus Idaho, Montana, Wyoming, North Dakota, and South Dakota - tend to cluster. The clustering of Illinois, Indiana, Ohio, Pennsylvania, Kentucky, Tennessee, and Alabama is also easily observable in the third quintile. In Figure 8, the clustering of Michigan, Indiana, Ohio, Pennsylvania, and New York is easily observable in the second quintile. In addition, states in the three highest quintiles tend to be located west of the Mississippi River, while states in the two lowest quintiles tend to be located east of the Mississippi River.

Determining whether the percentage changes in exports cluster, regardless of using total or known exports for either of the periods, reveals values close to zero, indicating no statistically significant association. For example, for the collapse, the Moran's I value is -0.12 for the percentage change in total exports and -0.11 for the percentage change in known exports. For the rebound, the corresponding values are -0.14 and -0.09 . Recall that the percentage changes in the intensive margin were relatively more important than the extensive margin in accounting for the percentage change in known exports, so finding that the pattern for the extensive margin does not lead to a pattern for known exports is not surprising.

\section{Demand Perspective}

As a final topic, I explore the impact of foreign demand on state exports. Consistent with the explanation that a decline in aggregate demand played the key role in the GTC, state exports would be expected to be tied to changes in the economic performance of a state's trading partners. A simple measure of the change in the economic performance of a state's trading partners is the trade-weighted growth of GDP. In other words, weighting each trading partner's growth in 2009 (2010) by its share of a state's trade in 2008 (2009) provides a measure of the overall performance of these trading partners. A reasonable expectation is that a states export growth in a specific year would be related positively to this summary measure of economic performance. Using known exports, I find correlation coefficients of 0.11 for the trade collapse and 0.12 for the trade rebound; however, for neither period do I find statistically significant relationships.

I also explore the possible connection between both the intensive and extensive margins and the trade-weighted growth of the state's trading partners. ${ }^{27} \mathrm{I}$ do not find statistically significant relationships between trade-weighted growth and percentage changes in the intensive margin for either period. The correlation is -0.08 for the collapse and 0.09 for the rebound. With respect to the extensive margin, a correlation coefficient of 0.48 suggests the larger trade-weighted declines in foreign growth were associated with larger percentage declines in the extensive margin during the collapse, but the correlation only slightly exceeds zero during the rebound. 


\section{Figure 5}

Intensive Margin (Distribution of Percentage Change in Average Exports per Firm, 2008-09)

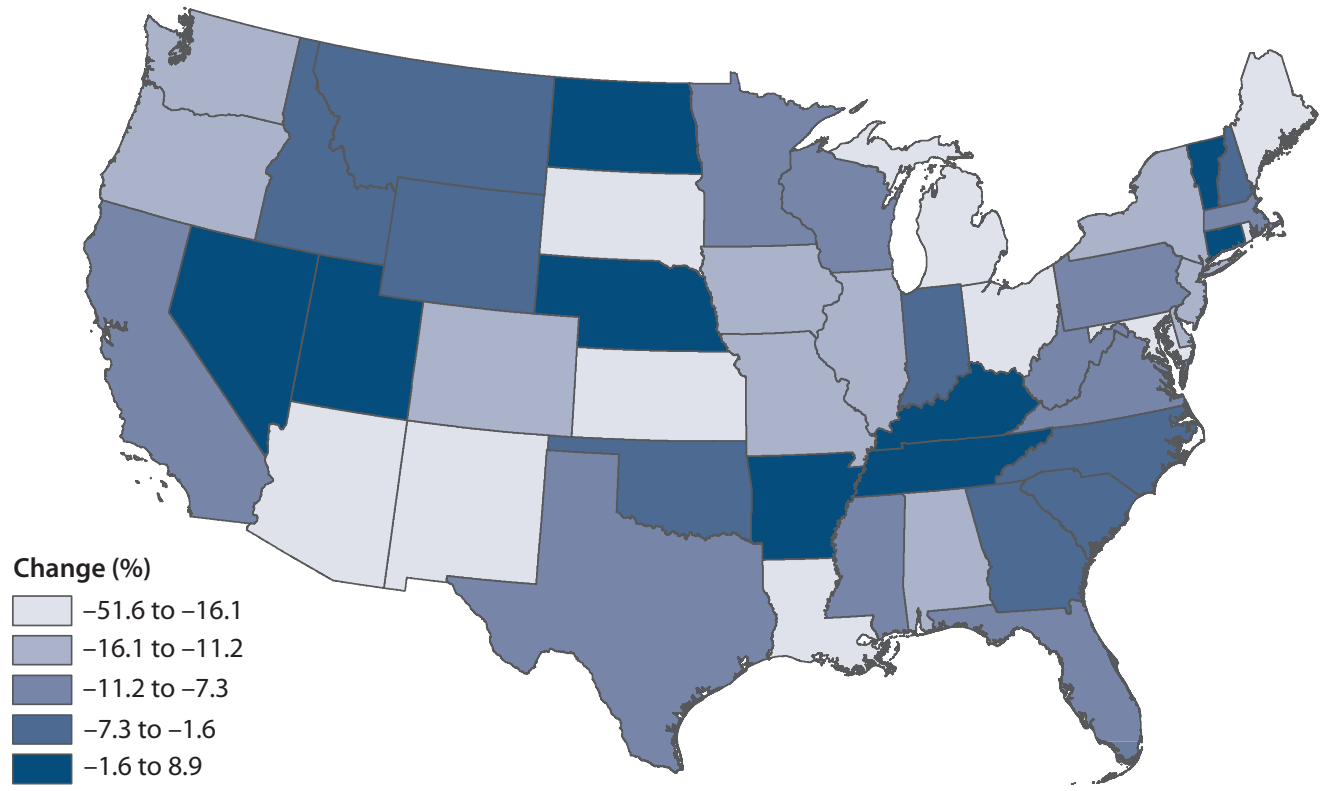

\section{Figure 6}

Intensive Margin (Distribution of Percentage Change in Average Exports per Firm, 2009-10)

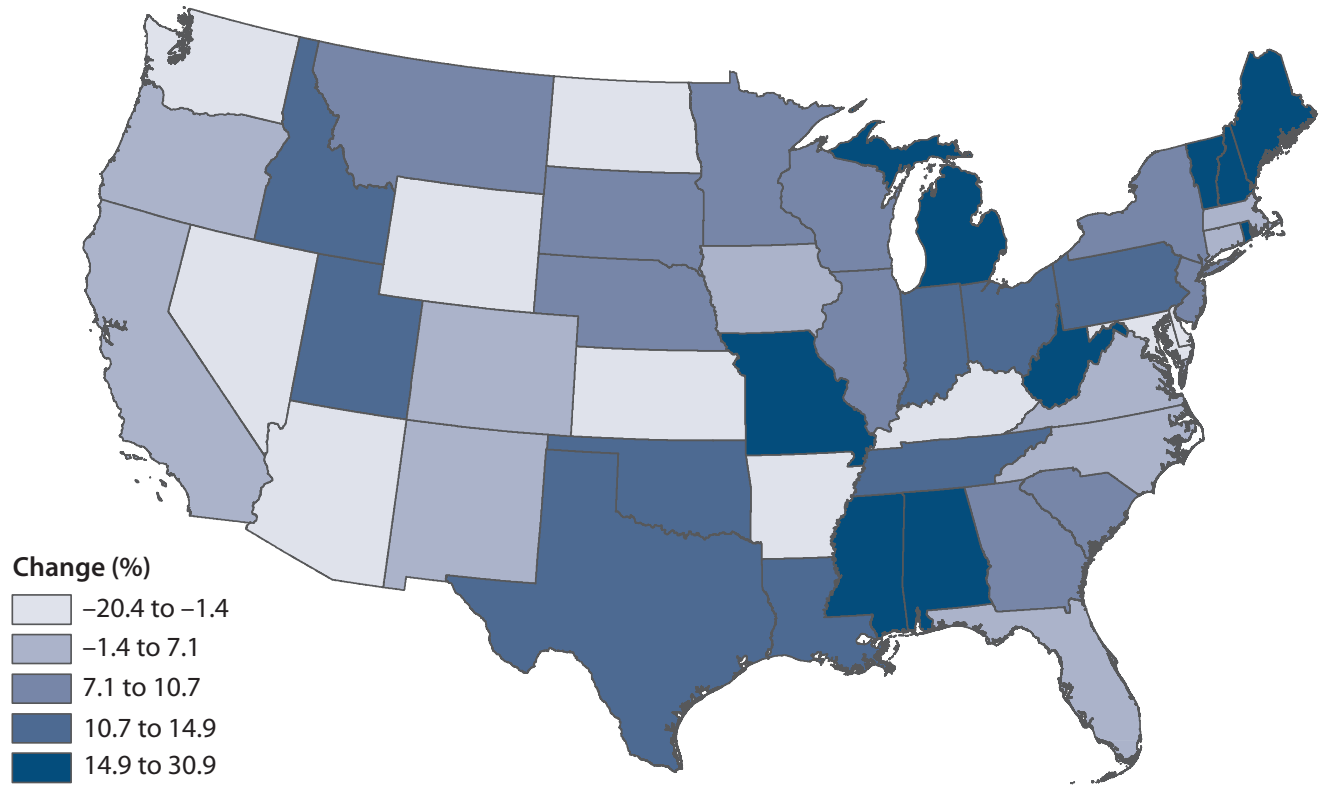




\section{Coughlin}

Figure 7

Extensive Margin (Distribution of Percentage Change in Number of Exporting Firms, 2008-09)

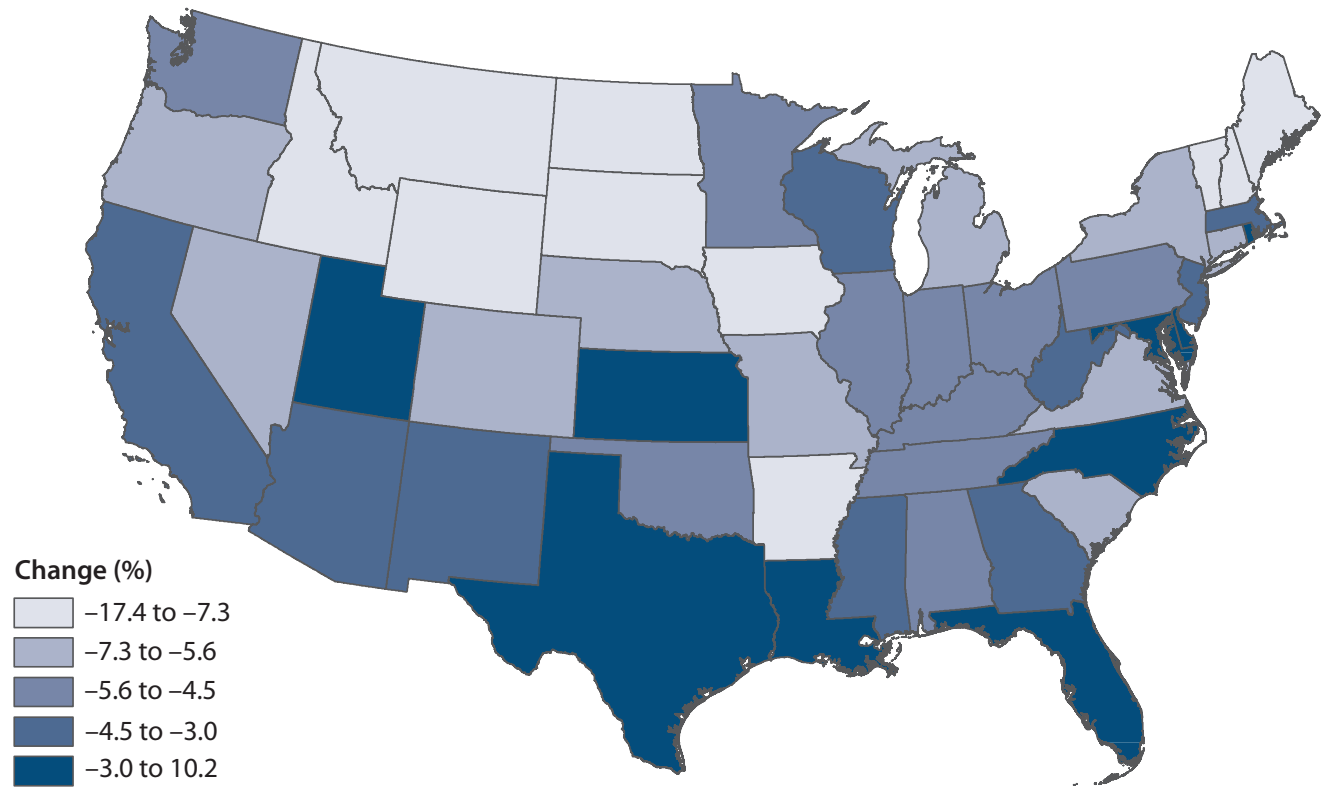

\section{Figure 8}

Extensive Margin (Distribution of Percentage Change in Number of Exporting Firms, 2009-10)

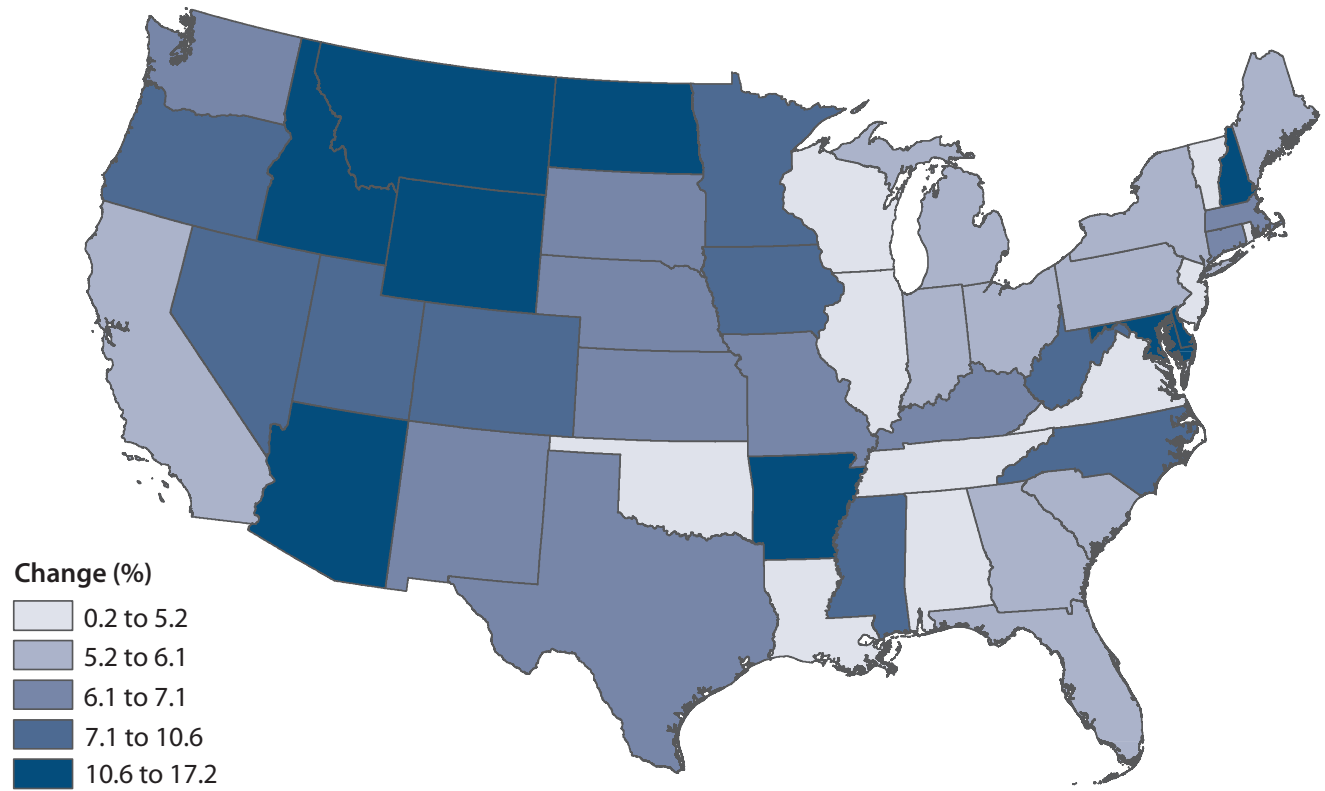




\section{SUMMARY AND CONCLUSION}

The GTC and its aftermath provide an excellent opportunity to examine the resiliency of the U.S. export sector. In contrast to previous studies, I examine this historic episode from the perspective of individual states. One concern during the GTC was that such a large collapse would transform firms from exporters into strictly domestic firms or, worse, drive them out of business. In either case, it was feared that U.S. exporting might, at best, revive slowly. Obviously, this fear about long-lived export impacts did not materialize. Thus, the U.S. experience during the GTC was similar to prior trade declines. Clearly, large export effects occurred, but the sharp decline during the GTC was quickly followed by a sharp rebound. In both periods, the percentage change in exports far exceeded the contemporaneous percentage change in GDP.

Examining the intensive and extensive trade margins shows that the adjustment occurred to a greater extent on the intensive than on the extensive trade margin. In other words, the adjustment process entailed relatively larger changes in average exports per firm than in the number of exporting firms. As indicated by the analysis of individual states, this finding at the national level is consistent with the results for the majority of states. It is likely much easier to alter existing export levels than to, first, eliminate all exports by a firm and, second, either restart exports by this firm or become a new entrant into exporting.

The findings in this article, which rely on state data, are consistent with previous work based on national data for numerous countries, including the United States, France, Japan, and Belgium. Moreover, the findings are consistent with current international trade theory that emphasizes productivity differences across firms and the importance of the additional costs that must be incurred to engage in international trade. ${ }^{28}$ Obviously, the more productive the firm, the more likely it will find exporting to be profitable. The increased costs associated with exporting include transportation costs, import duties, legal fees, marketing fees, and the development of distribution networks. Some of the increased costs can be viewed as market entry costs. Large and sunk market entry costs deter firms from exiting a foreign market, especially if a decline in demand is viewed as temporary. Rather than exiting, firms scale back their operations and wait for better times. When better times arrive, the firms ramp up their exports.

With respect to additional results, our examination of the time-related adjustment process revealed little association between the magnitudes of the trade collapses and the trade rebounds. In other words, I found states with the relatively larger collapses did not experience relatively larger (or smaller) rebounds. Similarly, I found no significant association between percentage changes in the intensive margins between the two periods. With respect to the extensive margin, I did find that relatively larger collapses were associated with relatively larger rebounds.

I found little association between state size and either the trade collapse or rebound experienced by states. I also found state size was not associated with the extent of the changes in the intensive margin but was associated with the extensive margin. Relatively larger states tended to have relatively smaller declines in their extensive margin during the trade collapse and smaller increases in their extensive margin during the trade rebound.

In comparing the similarity of a state's experience with those of its neighbors, I find no clustering in terms of percentage changes in exports during either the trade collapse or rebound. 
Similar to my previous results, I find no clustering of states with respect to the intensive margin, but I do find that the extensive margin experiences of nearby states are similar.

Finally, the growth of a state's trading partners does not systematically affect export growth during either the collapse or the rebound. This result might be caused by my reliance on annual data. It is possible that export changes lag the growth changes. Moreover, in addition to income, there may be other changes that obscure the impact of foreign growth. Similarly, an identified systematic relationship is lacking at the intensive margin during both periods. With respect to the extensive margin, I found that larger declines in foreign growth were associated with larger declines in the extensive margin during the collapse, but larger increases in foreign growth were not associated with larger increases in the extensive margin during the rebound.

The bottom line is that the U.S. export sector weathered the challenges associated with the global recession and financial crisis quite well. The fact that relatively large firms dominate U.S. exports likely contributes to the resiliency of the U.S. export sector. 


\section{NOTES}

1 The export data are Census-based rather than balance of payments-based. Annual data are highlighted because data for the analyses of trade margins at the state level are available only annually. Quarterly data show that U.S. exports of goods peaked in the third quarter of 2008. Exports declined during each of the next three quarters and then began to recover during the second half of 2009. By the fourth quarter of 2010, exports were slightly higher than the previous peak.

2 As noted in Baldwin (2009), the GTC is the steepest decrease in recorded history. Between World War II and the GTC, global trade declined three times: in 1974-75, 1982-83, and 2001-02. Bussière et al. (2013) state that on a year-over-year basis global trade declined more than 10 percent in real terms in 2009, while global real GDP fell 0.6 percent.

3 For a more technical examination of these hypotheses, see Bems, Johnson, and Yi (2013). Their conclusions match those of Crowley and Luo.

4 See Levchenko, Lewis, and Tesar (2010), Eaton et al. (2011), and Bussière et al. (2013) for analysis of compositional effects (e.g., the decline in demand was likely skewed toward tradable goods) and vertical specialization effects (e.g., firms spread their production processes across countries, so that the value of trade, entailing mostly intermediate goods, will necessarily exceed value added or GDP). In the latter case, declining demand is multiplied because of the increasing role of international supply chains. See Allesandria, Kaboski, and Midrigan (2010) for an analysis of inventory adjustments.

5 See Contessi and de Nicola (2013) for a review of the theoretical and empirical relationships between finance and international trade.

6 See Crowley and Luo (2011) and Bown and Crowley (2013). Eaton et al. (2011) also conclude that increased trade barriers had only a minimal effect on global declines in the ratio of trade to GDP.

7 Other studies using the Origin of Movement series include those by Smith (1999), Coughlin and Wall (2003), Coughlin (2004), Cassey (2009, 2011), and Coughlin and Novy (2013).

8 "Free alongside ship" means that the goods are delivered to a port to the point of loading aboard a vessel for shipment. Thus, the cost of the goods does not include the costs of moving the goods from alongside the vessel to the foreign buyer.

9 The most recent annual report is titled A Profile of U.S. Importing and Exporting Companies, 2010-2011 (http://www.census.gov/foreign-trade/Press-Release/edb/2011/edbrel.pdf). Two years are reported each year; the older year contains revised data and the more recent year contains data subject to revision.

${ }^{10}$ In other words, if the individual exporter can be identified, then the exports are said to be known. Total exports are determined by adding known exports and the exports for which no specific exporter can be identified.

${ }^{11}$ Because the share of known to total exports is virtually constant over 2008-10, the percentage changes in total and known exports are very similar: -18.3 versus -18.0 for $2008-09$ and 21.3 versus 21.1 for 2009-10.

${ }^{12}$ Our definitions of trade margins follow those of Lawless (2010) and Eaton, Kortum, and Kramarz (2004). As discussed by Lawless (2010), alternative definitions of these terms have appeared in the literature. Moreover, in the context of multiproduct firms, within-firm margins related to the number of products exported and average exports across products could be explored.

13 The decomposition of the percentage change in exports is straightforward: \% $\Delta X_{y 1, y 0}=\left[\left(\Delta F_{y 1, y 0} * X_{y 0} / F_{y 0}\right) / X_{y 0}\right]$ * $100+\left[\left(\left(\left(X_{y 1} / F_{y 1}\right)-\left(X_{y 0} / F_{y 0}\right)\right) * F_{y 0}\right) / X_{y 0}\right] * 100+\left[\left(\Delta F_{y 1} y 0 *\left(\left(X_{y 1} / F_{y 1}\right)-\left(X_{y 0} / F_{y 0}\right)\right) / X_{y 0}\right] * 100\right.$, where $X$ is the priceadjusted level of known exports, $F$ is the number of identified exporters, and the subscripts identify the years for the calculation. The first of the three right-hand-side terms is the extensive margin, the second is the intensive margin, and the third is the joint effect.

${ }^{14}$ The joint effect of the changes in the two margins is 0.4 percent.

${ }^{15}$ Such a finding is consistent with what is termed "hysteresis in trade"; see Baldwin (1988).

${ }^{16}$ Beginning with the destination for the most U.S. exports, the top 25 U.S exports destinations in 2010 were Canada, Mexico, China, Japan, the United Kingdom, Germany, Korea, Brazil, the Netherlands, Singapore, France, Hong Kong, Taiwan, Belgium, Australia, Switzerland, India, Italy, Malaysia, Colombia, the United Arab Emirates, Saudi Arabia, Israel, Chile, and Venezuela. 


\section{Coughlin}

17 See Cassey (2011) for a more thorough summary of state export patterns.

18 The simple correlation between state size in natural logarithms and the number of destination countries is 0.86 . Using state size in levels, the simple correlation is 0.57 . Both correlations are statistically significant at the 5 percent level.

${ }^{19}$ The simple correlation between GDP in natural logarithms and the number of states that export to a given country is 0.70 , which is statistically significant at the 5 percent level. Meanwhile, using GDP in levels, the simple correlation is 0.26 , which is also statistically significant at the 5 percent level.

20 The simple correlation between state size as measured by gross state product in natural logarithms and the number of exporting firms of plants in the state is 0.76 . Using state size in levels, the simple correlation is 0.94 . Both correlations are statistically significant at the 5 percent level.

${ }^{21}$ Depending on the situation, I use state-level total and known exports in my analysis. Simple correlations of total and known exports across states are virtually 1 for 2008, 2009, and 2010. The simple correlations of percentage changes in total and known exports across states for 2008-09 and 2009-10 are 0.89 and 0.97, respectively. This suggests that total and known exports are interchangeable for purposes of this article.

22 Utah is the only state that experienced an increase in both total and known exports. Total exports declined in Alaska during the collapse. All other states experienced declines in both total and known exports.

23 Simple correlations between the percentage changes in trade margins and exports reinforce this conclusion. The correlation between the intensive margin and exports is 0.93 , which is statistically significant at the 5 percent level, while the correlation between the extensive margin and exports is 0.13 , which is not statistically significant at the 5 percent level.

${ }^{24}$ Simple correlations between the percentage changes in trade margins and exports reinforce this conclusion. The correlation between the intensive margin and exports is 0.94 , which is statistically significant at the 5 percent level, while the correlation between the extensive margin and exports is -0.20 , which is not statistically significant at the 5 percent level.

${ }^{25}$ A simple illustration is a checkerboard with white and black squares. Normally, the white and black squares are dispersed yielding a Moran's I value close to -1. However, if all the white squares were placed together on one side of the board and the black squares on the other side, then the associated Moran's I value would be close to 1. A random arrangement would yield a value close to zero.

${ }^{26}$ Alaska and Hawaii are omitted because they have no contiguous states.

27 Increases in a foreign country's income, holding other things constant, should tend to increase a state's total exports to the country. However, as demonstrated by Lawless (2010), the effect in theory on the intensive margin is ambiguous. By inducing the entry of new exporting firms, average exports per firm may increase, decrease, or remain unchanged. Because of the induced entry of new exporters, the extensive margin in a state should increase as a foreign country's income increases.

${ }^{28}$ See Melitz (2003).

\section{REFERENCES}

Allesandria, George; Kaboski, Joseph P. and Midrigan, Virgiliu. "The Great Trade Collapse of 2008-09: An Inventory Adjustment?" IMF Economic Review, 2010, 58(2), pp. 254-94.

Baldwin, Richard. "Hysteresis in Import Prices: The Beachhead Effect." American Economic Review, September 1988, 78(4), pp. 773-85.

Baldwin, Richard, ed. The Great Trade Collapse: Causes, Consequences, and Prospects. VoxEU.Org eBooks, 2009; http://www.voxeu.org/epubs/cepr-reports/great-trade-collapse-causes-consequences-and-prospects.

Behrens, Kristian; Corcos, Gregory and Mion, Giordano. "Trade Crisis? What Trade Crisis?" Review of Economics and Statistics, May 2013, 95(2), pp. 702-09.

Bems, Rudolfs; Johnson, Robert C. and Yi, Kei-Mu. "The Great Trade Collapse." Annual Review of Economics, 2013, 5, pp. 375-400. 
Bown, Chad P. and Crowley, Meredith A. "Import Protection, Business Cycles, and Exchange Rates: Evidence from the Great Recession." Journal of International Economics, May 2013, 90(1), pp. 50-64.

Bussière, Matthieu; Callegari, Giovanni; Ghironi, Fabio; Sestieri, Giulia and Yamano, Norihiko. "Estimating Trade Elasticities: Demand Composition and the Trade Collapse of 2008-2009." American Economic Journal: Macroeconomics, July 2013, 5(3), pp. 118-51.

Cassey, Andrew J. "State Export Data: Origin of Movement vs. Origin of Production." Journal of Economic and Social Measurement, 2009, 34(4), pp. 241-68.

Cassey, Andrew J. “State Foreign Export Patterns." Southern Economic Journal, October 2011, 78(2), pp. 308-29.

Chor, Davin and Manova, Kalina. "Off the Cliff and Back? Credit Conditions and International Trade During the Global Financial Crisis." Journal of International Economics, May 2012, 87(1), pp. 117-33.

Contessi, Silvio and de Nicola, Francesca. "What Do We Know About the Relationship Between Access to Finance and International Trade?" Working Paper No. 2012-054B, Federal Reserve Bank of St. Louis, March 2013; http://research.stlouisfed.org/wp/2012/2012-054.pdf.

Coughlin, Cletus C. "The Increasing Importance of Proximity for Exports from U.S. States." Federal Reserve Bank of St. Louis Review, November/December 2004, 86(6), pp. 1-18; http://research.stlouisfed.org/publications/review/04/11/Coughlin.pdf.

Coughlin, Cletus C. and Novy, Dennis. "Is the International Border Effect Larger than the Domestic Effect? Evidence from U.S. Trade." CESifo Economic Studies, June 2013, 59(2), pp. 249-76; doi:10.1093/cesifo/ifs002.

Coughlin, Cletus C. and Wall, Howard J. "NAFTA and the Changing Pattern of State Exports." Papers in Regional Science, October 2003, 82(4), pp. 427-50.

Crowley, Meredith A. and Luo, Xi. "Understanding the Great Trade Collapse of 2008-09 and the Subsequent Trade Recovery." Federal Reserve Bank of Chicago Economic Perspectives, Second Quarter 2011, 35(2), pp. 44-70; http://www.chicagofed.org/digital_assets/publications/economic_perspectives/2011/2qtr2011_part1_crowley_luo.pdf.

Eaton, Jonathan; Kortum, Samuel and Kramarz, Francis. “Dissecting Trade: Firms, Industries, and Export Destinations." American Economic Review, May 2004, 94(2), pp. 150-54.

Eaton, Jonathan; Kortum, Samuel; Neiman, Brent and Romalis, John. "Trade and the Global Recession." NBER Working Paper No. 16666, National Bureau of Economic Research, January 2011; http://www.nber.org/papers/w16666.pdf?new_window=1.

Fontagné, Lionel and Gaulier, Guillaume. "French Exporters and the Global Crisis," in Richard Baldwin, ed., The Great Trade Collapse: Causes, Consequences and Prospects. Chap. 16. VoxEU.Org eBooks, 2009; http://www.voxeu.org/article/french-exporters-and-global-crisis.

Lawless, Martina. "Deconstructing Gravity: Trade Costs and Extensive and Intensive Margins." Canadian Journal of Economics, November 2010, 43(4), pp. 1149-72.

Levchenko, Andrei A.; Lewis, Logan T. and Tesar, Linda L. “The Collapse of International Trade during the 2008-2009 Crisis: In Search of the Smoking Gun." IMF Economic Review, 2010, 58(2), pp. 214-53.

Melitz, Marc J. "The Impact of Trade on Intra-Industry Reallocations and Aggregate Industry Productivity." Econometrica, November 2003, 71(6), pp. 1695-725.

Schott, Peter K. "US Trade Margins during the 2008 Crisis," in Richard Baldwin, ed., The Great Trade Collapse: Causes, Consequences and Prospects. Chap. 15. VoxEU.Org eBooks, 2009;

http://www.voxeu.org/article/us-trade-margins-during-2008-crisis.

Smith, Pamela J. "Are Weak Patent Rights a Barrier to U.S. Exports?" Journal of International Economics, June 1999, 48(1), pp. 151-77.

Wakasugi, Ryuhei. "Why Was Japan's Trade Hit So Much Harder?” in Richard Baldwin, ed., The Great Trade Collapse: Causes, Consequences and Prospects. Chap. 23. VoxEU.Org eBooks, 2009;

http://www.voxeu.org/article/why-was-japan-s-trade-hit-so-much-harder. 
